\title{
Association of DNA topoisomerase I and RNA polymerase I: a possible role for topoisomerase $I$ in ribosomal gene transcription
}

\author{
Kathleen M. Rose ${ }^{1}$, Jan Szopa ${ }^{1}$, Fu-Sheng Han ${ }^{2}$, Yung-Chi Cheng ${ }^{2}$, Arndt Richter ${ }^{3}$, and Ulrich Scheer ${ }^{4}$ \\ ${ }^{1}$ Department of Pharmacology, Medical School, University of Texas Health Science Center, Houston, TX 77225, USA \\ ${ }^{2}$ Department of Pharmacology, University of North Carolina School of Medicine, Chapel Hill, NC 27514, USA \\ ${ }^{3}$ Fakultät für Biologie, Universität Konstanz, D-7750 Konstanz, Federal Republic of Germany \\ ${ }^{4}$ Institute of Zoology I, University of Würzburg, Röntgenring 10, D-8700 Würzburg, Federal Republic of Germany
}

\begin{abstract}
RNA polymerase I preparations purified from a rat hepatoma contained DNA topoisomerase activity. The DNA topoisomerase associated with the polymerase had an $\mathrm{M}_{\mathrm{r}}$ of 110000 , required $\mathrm{Mg}^{2+}$ but not $\mathrm{ATP}$, and was recognized by anti-topoisomerase I antibodies. When added to RNA polymerase I preparations containing topoisomerase activity, anti-topoisomerase I antibodies were able to inhibit the DNA relaxing activity of the preparation as well as RNA synthesis in vitro. RNA polymerase II prepared by analogous procedures did not contain topoisomerase activity and was not recognized by the antibodies. The topoisomerase I: polymerase I complex was reversibly dissociated by column chromatography on Sephacryl S200 in the presence of $0.25 \mathrm{M}\left(\mathrm{NH}_{4}\right)_{2} \mathrm{SO}_{4}$. Topoisomerase I was immunolocalized in the transcriptionally active ribosomal gene complex containing RNA polymerase I in situ. These data indicate that topoisomerase I and RNA polymerase I are tightly complexed both in vivo and in vitro, and suggest a role for DNA topoisomerase I in the transcription of ribosomal genes.
\end{abstract}

\section{Introduction}

The DNA topoisomerases are a group of enzymes with the ability to interconvert topological isomers of DNA by breaking and resealing phosphodiester bonds (for recent reviews see Liu 1984; Vosberg 1985; Wang 1985). Type I topoisomerase, first described in prokaryotes by Wang (1971) and in eukaryotes by Champoux and Dulbecco (1972) and later characterized by Keller (1975a, b), change the linking number in steps of one. Although their biological function is not completely defined, this class of topoisomerase has been implicated in transcriptional (Akrigg and Cook 1980; Dynan and Burgess 1981; Sternglanz et al. 1981; Weisbrod 1982; Fleischmann et al. 1984; Gilmour et al. 1986; Shastry 1986) as well as in recombinational and replicational (Kikuchi and Nash 1979; Sternglanz et al. 1981; also see Gellert 1981; Bullock et al. 1985; Zeng et al. $1985)$ events. In higher eukaryotes topoisomerase I is enriched in the nucleolus (Fleischmann et al. 1984; Muller et al. 1985) and may play a role in transcription of supercoiled rDNA in vitro (Garg et al. 1987). Studies in Tetrahymena indicate that the ribosomal DNA-associated enzyme

Offprint requests to: K.M. Rose is located at DNase I hypersensitive sites in the nontranscribed rDNA spacer region (Bonven et al. 1985). In vitro the activity of topoisomerase I is inhibited by polyADPribosylation (Jonstra-Bilen et al. 1983; Ferro and Olivers 1984). Conversely, the activity is stimulated when the enzyme is phosphorylated by casein kinase II (Durban et al. 1985).

The DNA-dependent enzyme, RNA polymerase I, is responsible for the transcription of ribosomal genes (for reviews see Roeder 1976; Jacob and Rose 1978). This polymerase is associated with actively transcribed nucleolar genes and is localized in the fibrillar center of that organelle (Scheer and Rose 1984). Further, RNA polymerase I is phosphorylated by a type II casein kinase, nuclear protein kinase NII (Rose et al. $1981 \mathrm{a}, \mathrm{b}$ ), and this modification enhances transcription (Duceman et al. 1981; Rose et al. 1983). Taken together with the observations concerning topoisomerase I these data suggest an intriguing relationship between topoisomerase I and RNA polymerase I. We now wish to report that a topoisomerase I activity is reversibly associated with highly purified preparations of RNA polymerase I and that inhibition of the topoisomerase activity of the complex inhibits transcription. Further, topoisomerase I is shown to be present in the active ribosomal gene transcription complex in situ.

\section{Materials and methods}

Enzyme purification. RNA polymerase I was purified by sequential column chromatography on DEAE-Sephadex, Affi-gel Blue and heparin-Sepharose followed by sedimentation on sucrose gradients essentially as described previously (Rose et al. $1981 \mathrm{a}$ ) except that $25 \%$ glycerol was included and $0.2-0.25 \mathrm{M}\left(\mathrm{NH}_{4}\right)_{2} \mathrm{SO}_{4}$ sometimes replaced $\mathrm{KCl}$ in the sucrose gradient buffer (sedimentation time was increased to $16 \mathrm{~h}$ to accommodate the increased viscosity of the gradient). Purified RNA polymerase I had a specific activity of $100 \mathrm{nmol}$ UMP incorporated in $30 \mathrm{~min}$ per milligram protein measured under optimal conditions (Rose et al. 1976). Topoisomerase I was obtained from the sucrose gradient of the polymerase preparation. Fractions that sedimented from approximately $7-10 \mathrm{~S}$ were pooled and purified in a manner analogous to that described for protein kinase NII (Rose et al. 1981 a). The final step in the purification, ATP-Sepharose chromatography, separated the remaining protein kinase from the topoisomerase, which eluted in the flow-through fractions. Purified topoisomerase 
had a specific activity of 150000 units per milligram protein. One unit represents the capacity to relax $1 \mu \mathrm{g}$ supercoiled DNA in $30 \mathrm{~min}$ at $37^{\circ} \mathrm{C}$.

Topoisomerase assay. Reactions ( $26 \mu \mathrm{l}$ final volume) contained $5 \mathrm{mM} \mathrm{MgCl}_{2}, 0.1 \mathrm{mM}$ EDTA, $25 \mathrm{mM} \mathrm{KCl}$, enzyme diluted in buffer containing final concentrations of $0.2 \mathrm{mM}$ dithiothreitol, $20 \mathrm{mM}$ Tris- $\mathrm{Cl}$, pH 7.9, 20\% glycerol, and $160 \mathrm{ng}$ pBR322 DNA (obtained from BRL, approximately $75 \%$ in the supercoiled form). Following incubation for $45 \mathrm{~min}$ at $37^{\circ} \mathrm{C}$, reactions were terminated by addition of $1 \mu \mathrm{l}$ of solution containing $1 \%$ sodium dodecyl sulfate, $0.25 \%$ xylene cyanol, $0.25 \%$ bromophenol blue and $30 \%$ glycerol. Samples were loaded onto a $0.5 \%$ agarose gel and electrophoresis was carried out at $30 \mathrm{~V}$ for $16 \mathrm{~h}$ at $23^{\circ} \mathrm{C}$ in buffer containing $40 \mathrm{mM}$ Tris-acetate, $\mathrm{pH} 8,1 \mathrm{mM}$ EDTA. Following electrophoresis, the gels were immersed in ethidium bromide solution $(40 \mathrm{ng} / \mathrm{ml})$ for $30 \mathrm{~min}$ and destained in $\mathrm{H}_{2} \mathrm{O}$ for 1-2 h. DNA was visualized with a Photodyne 3-3000 UV transilluminator. In those instances in which electrophoresis was conducted in the presence of ethidium bromide (relaxation assay), the intercalating agent was included in the running buffer at a concentration of $20 \mathrm{ng} / \mathrm{ml}$. To enhance visualization, these gels were also immersed in ethidium bromide following electrophoresis. Data were quantitated by laser beam densitometry.

RNA polymerase assay and immunoblotting. RNA synthesis was measured as described previously (Szopa and Rose 1986). Immunoblotting was also conducted as described therein.

Anti-topoisomerase antibodies. Monoclonal antibodies against human topoisomerase I were prepared by a modification of the technique described by Köhler and Milstein (1975). A complete description of the protocol will be presented elsewhere (F.S. Han and Y-C. Cheng, in preparation). Antibodies were purified by DEAE-Affi gel Blue or protein A-Sepharose chromatography and dialyzed into buffer containing $0.1 \mathrm{M}$ Tris-Cl, $\mathrm{pH}$ 7.4. Polyclonal antibodies were prepared by immunization of rabbits with topoisomerase I purified from calf thymus. Immunoglobulins were purified by protein A-Sepharose chromatography. Monospecific antibodies were prepared by elution with 10 mM Hepes, pH 2.8 (Fleischmann et al. 1984) from immunoblots of topoisomerase I.

Immunofluorescence microscopy. An established rat cell line (RV-SMC) was prepared for immunofluorescence microscopy as described (Scheer and Rose 1984). The cells were incubated with affinity purified rabbit antibodies to topoisomerase I $(15 \mu \mathrm{g} / \mathrm{ml}$ in PBS for $20 \mathrm{~min}$ at room temperature), washed several times in PBS followed by incubation with FITC-labeled anti-rabbit IgG diluted 1:20 (Dianova, Hamburg, FRG). In some experiments cells were exposed for $6 \mathrm{~h}$ to $50 \mu \mathrm{g} / \mathrm{ml} \mathrm{5,6-dichloro-D-ribofuranosylbenzimida-}$ zole (DRB) (Scheer et al. 1984) prior to immunostaining.

\section{Results}

First we evaluated whether topoisomerase activity was present in purified RNA polymerase preparations. As shown in Figure 1, a highly purified polymerase I fraction isolated from sucrose gradients performed in $0.3 \mathrm{M} \mathrm{KCl}$ was able to change the linking number of superhelical (form I) DNA. This activity was dependent on both enzyme concentration

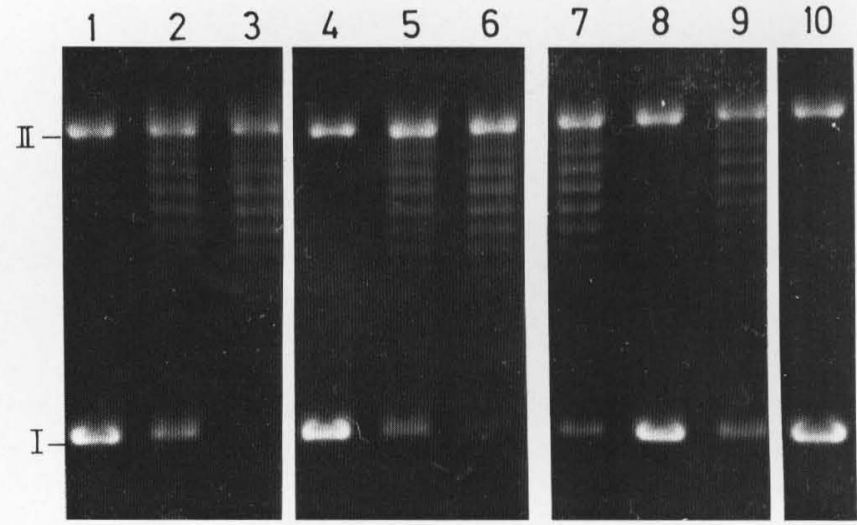

Fig. 1. Topoisomerase activity associated with purified RNA polymerase I. RNA polymerase I was purified through sucrose gradients and analyzed for topoisomerase activity as described in Materials and methods. Lanes $1-3$, products obtained from reactions containing 165,247 , and $330 \mathrm{ng}$ of RNA polymerase I, respectively, incubated for $45 \mathrm{~min}$ at $37^{\circ} \mathrm{C}$. Lanes 4-6, DNA from reactions containing $330 \mathrm{ng}$ of polymerase I, incubated at the same temperature for 0,10 , and $30 \mathrm{~min}$, respectively. Lanes $7-9$, products from reactions containing $500 \mathrm{pg}$ topoisomerase purified as described in Materials and methods and incubated for $45 \mathrm{~min}$ at $37^{\circ} \mathrm{C}$ under normal reaction conditions (lane 7), and the absence of $\mathrm{MgCl}_{2}$ (lane 8), or in the presence of $0.5 \mathrm{mM}$ ATP (lane 9). Lane 10, DNA incubated in the absence of enzyme. I and II, supercoiled form I and open circular form II DNAs, respectively

(Fig. 1, lanes 1-3) and time (lanes 4-6). The activity required $\mathrm{Mg}^{++}$but not ATP and was stimulated in the presence of 25-50 mM KCl (not shown).

To compare this activity with that of a pure topoisomerase, we isolated a topoisomerase independent of RNA polymerase. Preliminary experiments indicated that the bulk of the ATP-independent topoisomerase activity in the nuclear extracts used for purification of RNA polymerase I copurified with this polymerase. The last step in polymerase I purification is sedimentation through sucrose gradients in the presence of $0.3 \mathrm{M} \mathrm{KCl}$ (Rose et al. $1981 \mathrm{a}$ ) or $0.25 \mathrm{M}$ $\left(\mathrm{NH}_{4}\right)_{2} \mathrm{SO}_{4}$ (for optimal release of associated polypeptides) Because of the large size of the polymerase $(>15 \mathrm{~S})$ and the presence of the salt this step is efficient in the removal of enzyme-bound polypeptides. Thus, the upper fractions of the gradient can be used for the further purification of proteins that have an affinity for the enzyme but are released by the high salt and/or by the shear forces of the gradient as well as for purification of enzyme subunits that have "disassembled" during the gradient stage. Topoisomerase I was purified from the fractions of the gradient containing both protein kinase NII (approximately 6-7S ; Rose et al. 1981 a) and topoisomerase activities. The topoisomerase copurified with the kinase through the caseinand phosvitin-Sepharose columns but, unlike the kinase, was not retained on the ATP-Sepharose columns. The purified topoisomerase activity was dependent on both time and enzyme concentration (not shown) and required $\mathrm{Mg}^{++}$, but not ATP (Fig. 1, lanes 7-9).

The purified topoisomerase appeared to be a single polypeptide with an $\mathrm{Mr}$ of 110000 as estimated by analysis on polyacrylamide gels in the presence of sodium dodecyl sulphate (Fig. 2, lane 1). The size of this topoisomerase, coupled with its enzymatic properties suggested that it was a type I topoisomerase. To confirm this, the purified enzyme was analyzed by immunoblotting using monoclonal 


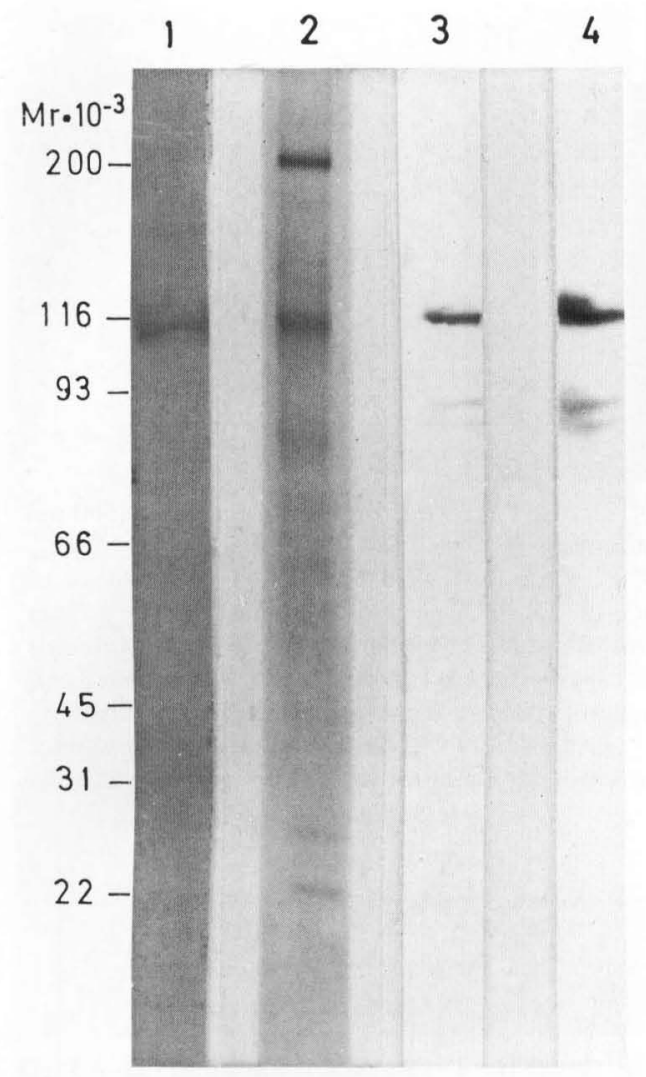

Fig. 2. Immunoblotting of topoisomerase I and RNA polymerase I. Topoisomerase I and RNA polymerase I were purified as described in Material and methods and subjected to linear polyacrylamide gradient $(4.5 \%-12.5 \%)$ gel electrophoresis essentially as described by Laemmli (1970). Lane 1, topoisomerase I, $1 \mu \mathrm{g}$, stained with Coomassie Blue; lane 2, RNA polymerase I, $70 \mathrm{ng}$, stained with silver. Proteins from analogous gels were transferred to nitrocellulose and reacted with anti-topoisomerase antibodies (lanes 3 and 4 ) as described in Materials and methods. Lane 3, topoisomerase I $(1 \mu \mathrm{g})$; lane 4 , RNA polymerase I $(10 \mu \mathrm{g})$

antibodies against topoisomerase I. As shown in Figure 2, lane 3, the antibodies recognized the $110000 \mathrm{M}_{\mathrm{r}}$ polypeptide. Two smaller polypeptides, not visible on the proteinstained gel, were also detected on the immunoblots; presumably these were cleavage products since they are not observed in freshly prepared enzyme preparations (see also Schmitt et al. 1984; Guldner et al. 1986; Shero et al. 1986). To evaluate whether RNA polymerase I preparations contained a similar topoisomerase they were analyzed in an analogous manner. As indicated in Figure 2, lane 2, purified RNA polymerase I purified on sucrose gradients containing $0.3 \mathrm{M} \mathrm{KCl}$ contains several polypeptides; most evident are those of $M_{r} 190000$ and 110000 . The minor bands shown in this gel are degradation products of the $M_{r} 190000$ polypeptide. When larger quantities of the enzyme are applied to the gel, the smaller polypeptides, $\left(\mathrm{M}_{\mathrm{r}} 65000,42000\right.$, 25000 ) associated with the polymerase, can be visualized. As shown in Figure 2, lane 4, the monoclonal antibodies against topoisomerase I reacted with an $\mathrm{M}_{\mathrm{r}} 110000$ polypeptide of the RNA polymerase I preparation. As an aside it should be mentioned that RNA polymerase II purified by methods analogous to polymerase I neither contained topoisomerase activity nor reacted with the anti-topoisomerase antibodies on immunoblots (not shown). A re- cent report based on in vivo crosslinking has also provided evidence that RNA polymerase II and topoisomerase I are not tightly associated but interact independently with transcribed sequences (Gilmour et al. 1986).

To evaluate whether the association between RNA polymerase I and topoisomerase had any functional significance, we examined RNA synthesis in the presence of the anti-topoisomerase antibodies. We chose a range of antibody concentrations that were capable of preventing the conversion of negatively super-coiled DNA to the relaxed form. As can be seen in Figure 3, lanes 3-7, in the presence of the antibodies, the topoisomerase activity in the polymerase preparation was able to open the negatively super-coiled DNA, but not to reseal it. It should be noted that inhibition of an equivalent amount of relaxing activity of the purified topoisomerase (separated from polymerase) required less antibody (Fig. 3, lane 14). Whether the need to use more antibodies to inhibit the polymerase I-associated enzyme reflected the presence of inactive topoisomerase molecules or restricted access of the antibodies to their binding sites as a result of association of the topoisomerase with the polymerase is not known. In a separate experiment we examined the effect of the topoisomerase antibodies on RNA synthesis. As shown in Figure 4, RNA polymerase I activity was inhibited by the topoisomerase antibodies. Similar concentrations of immunoglobulins purified from normal mouse serum had no effect on RNA synthesis. Using the same anti-topoisomerase antibody preparation, inhibition of the purified topoisomerase was also observed. As had been observed in Figure 3, it required less antibody to inhibit the isolated topoisomerase activity. To evaluate whether the topoisomerase was tightly bound to the polymerase, we immobilized anti-topoisomerase antibodies on DEAE Affi-gel Blue or protein A-Sepharose beads, and added them to RNA polymerase I. In two different experiments, beads containing the anti-topoisomerase I antibodies removed $45 \%-47 \%$ of the polymerase I activity from solution, whereas beads containing control immunoglobulins removed less than $5 \%$ of the enzyme activity. To determine whether the antibody-induced inhibition of RNA polymerase I was nonspecific, we added topoisomerase I to RNA polymerase II and then added the anti-topoisomerase antibodies; no inhibition was observed in this case.

The foregoing suggested that polymerase I and topoisomerase I formed a complex in vitro. To ascertain whether this was a reversible complex we tried to dissociate the enzymes by gel filtration chromatography under various salt conditions. Initial experiments suggested that the $\mathrm{M}_{\mathrm{r}} 110000$ topoisomerase coeluted with the $\mathrm{M}_{\mathrm{r}} 500000$ 600000 polymerase at $\mathrm{NaCl}$ or $\mathrm{NH}_{4} \mathrm{Cl}$ concentrations up to $0.8 \mathrm{M}$. However, when $0.25 \mathrm{M}\left(\mathrm{NH}_{4}\right)_{2} \mathrm{SO}_{4}$ was used as the salt the enzymes could be dissociated into separately eluting entities (Fig. 5A). The polymerase I: topoisomerase I complex was completely reversible and the enzymes in the reconstituted complex coeluted at $20 \mathrm{mM}\left(\mathrm{NH}_{4}\right)_{2} \mathrm{SO}_{4}$ (Fig. 5B). For comparison, the elution profiles of the dissociated enzymes individually subjected to chromatography at $20 \mathrm{mM}\left(\mathrm{NH}_{4}\right)_{2} \mathrm{SO}_{4}$ are shown in Figure $5 \mathrm{C}$ (topoisomerase) and $\mathrm{D}$ (polymerase). Note that at $20 \mathrm{mM}\left(\mathrm{NH}_{4}\right)_{2} \mathrm{SO}_{4}$, the topoisomerase alone does not aggregate and elutes at the same elution volume as under the $0.25 \mathrm{M}\left(\mathrm{NH}_{4}\right)_{2} \mathrm{SO}_{4}$ conditions.

Using immunocytochemical methods, we have previously demonstrated the presence of RNA polymerase I 


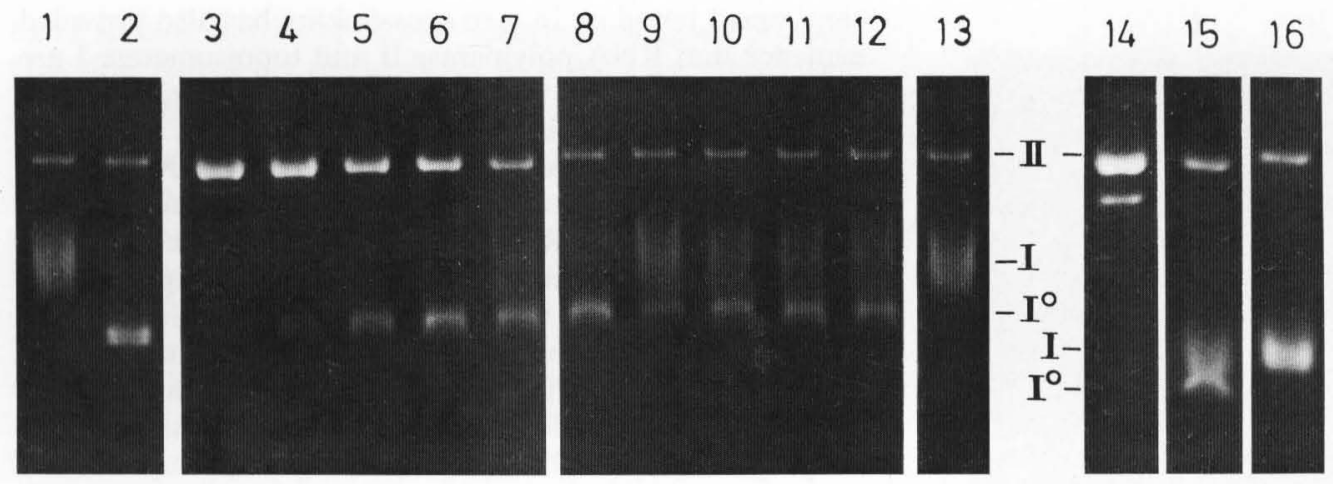

Fig. 3. Inhibition of topoisomerase activity by anti-topoisomerase antibodies. RNA polymerase I ( $260 \mathrm{ng}$ ) or topoisomerase I (500 pg) were preincubated with anti-topoisomerase antibodies for $20 \mathrm{~min}$ at $30^{\circ} \mathrm{C}$ in buffer containing $40 \mathrm{mM} \mathrm{Tris-Cl,} \mathrm{pH} 7.5,5 \mathrm{mM} \mathrm{MgCl}$, $0.1 \mathrm{mM}$ EDTA. DNA was then added and the reactions incubated for $45 \mathrm{~min}$ at $37^{\circ} \mathrm{C}$. Reactions were terminated by addition of sodium dodecyl sulfate $\left(0.5 \%\right.$ final concentration). Following incubation in the presence of $2 \times 10^{-3}$ units of proteinase $\mathrm{K}$ for 15 min at $37^{\circ} \mathrm{C}$, reaction products were processed on $0.5 \%$ agarose gels containing $0.02 \mu \mathrm{g} / \mathrm{ml}$ ethidium bromide as described in Materials and methods. Lanes 1, 13 and 16, DNA processed in the absence of enzyme. Lanes 2-12, RNA polymerase I. Lanes 14, 15, topoisomerase I. Lanes 3-7, RNA polymerase incubated in the presence of $3.85,1.92,0.96,0.48$, and $0.24 \mu$ g anti-topoisomerase IgG, respectively. Lanes 8 12 , enzyme incubated in the presence of identical concentrations of normal mouse IgG. Lanes 13, 16, DNA incubated in the presence of $1.70 \mu \mathrm{g}$ normal mouse IgG. Lanes 14,15 , topoisomerase incubated with $0.24 \mu \mathrm{g}$ anti-topoisomerase and normal mouse IgG, respectively. $I$ Supercoiled, $I^{\circ}$ closed circular relaxed and $I I$ open circular form DNAs

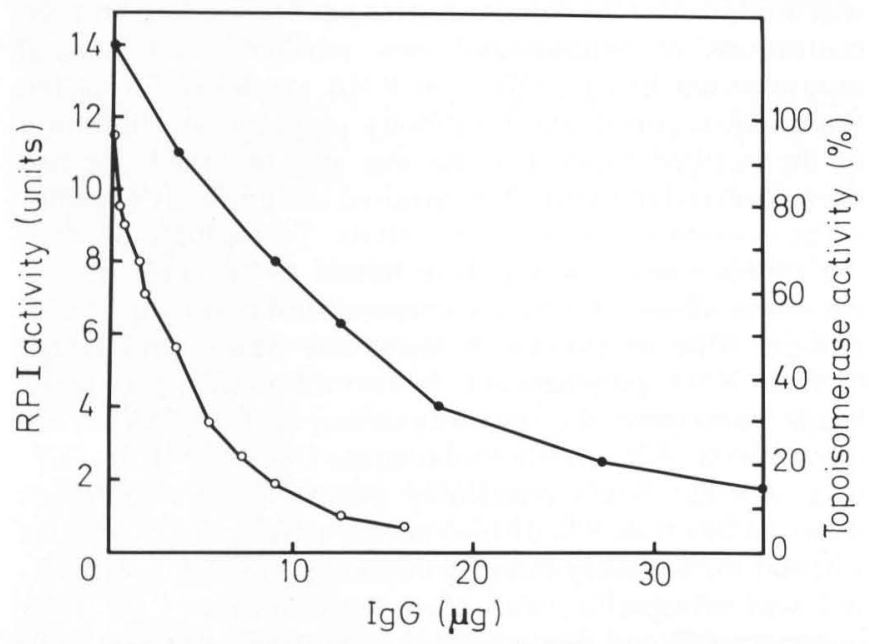

Fig. 4. Effect of anti-topoisomerase antibodies on RNA synthesis. RNA polymerase I was preincubated for $5 \mathrm{~min}$ at $30^{\circ} \mathrm{C}$ with antitopoisomerase antibodies as indicated. RNA synthesis was then measured by incubation with DNA and appropriate cofactors as described (Szopa and Rose 1986) (•). In a parallel experiment, the antibodies were preincubated with topoisomerase I purified from the hepatoma and topoisomerase activity measured, and conversion of form I to form II DNA quantitated by laser beam densitometry (o). Addition of 15-40 $\mu \mathrm{g}$ of normal mouse immunoglobulins purified in an analogous manner to the anti-topoisomerase antibodies had no effect on either RNA synthesis or topoisomerase activity

in the active ribosomal gene transcription complex (Scheer and Rose 1984; Scheer et al. 1984). To investigate whether topoisomerase I is associated with ribosomal genes in situ we examined the localization of topoisomerase $\mathrm{I}$ in an established rat cell line. As shown in Figure 6A, B, affinity purified rabbit polyclonal antibodies raised against topoisomerase I stained the nucleoli of these cells very strongly. In addition, the whole nucleoplasm was stained in a finely punctate pattern. In cells treated with DRB, the nucleolar architecture is disrupted (Fig. 6C) and the RNA-containing chromatin extended (Scheer et al. 1984). In spite of this,

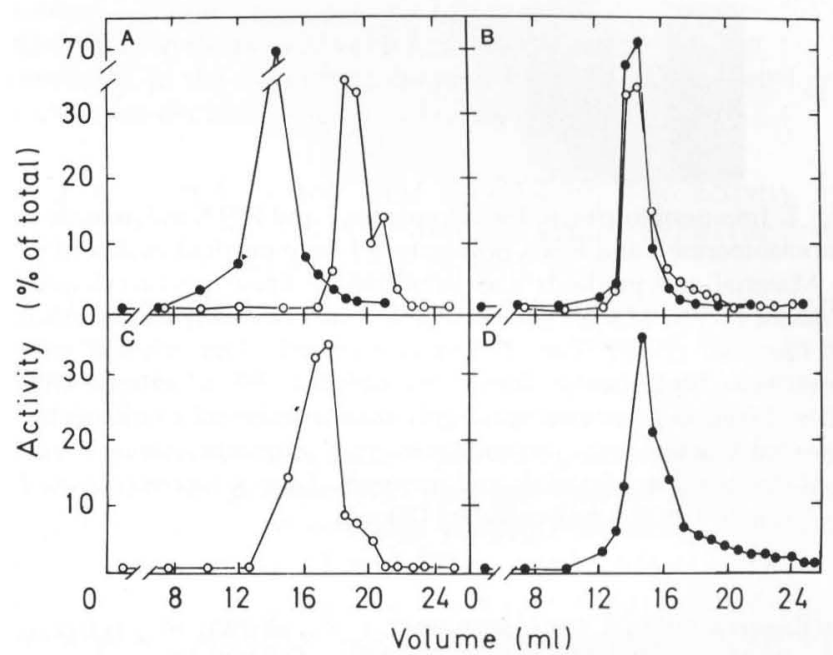

Fig. 5A-D. Reversible dissociation of RNA polymerase and topoisomerase: analysis by gel filtration chromatography. A $300 \mu 1$ sample containing the RNA polymerase: topoisomerase complex or the individual enzymes was applied to a $0.75 \times 26 \mathrm{~cm}$ Sephacryl S200 column equilibrated in buffer containing $50 \mathrm{mM}$ Hepes-Cl, $\mathrm{pH} 7.9,25 \%$ glycerol, $0.1 \mathrm{mM}$ EDTA, $0.5 \mathrm{mM}$ dithiothreitol and either $0.25 \mathrm{M}\left(\mathrm{NH}_{4}\right)_{2} \mathrm{SO}_{4}(\mathbf{A})$ or $20 \mathrm{mM}\left(\mathrm{NH}_{4}\right)_{2} \mathrm{SO}_{4}(\mathbf{B}-\mathbf{D})$. The column was developed with the same buffer, $0.8 \mathrm{ml}$ fractions collected and enzyme aliquots analyzed for RNA polymerase $(\bullet)$ or topoisomerase (o) activity. A RNA polymerase I containing topoisomerase, obtained from the heparin Sepharose stage of purification, was adjusted to a final concentration of $0.25 \mathrm{M}\left(\mathrm{NH}_{4}\right)_{2} \mathrm{SO}_{4}$ prior to column application. B-D RNA polymerase I and topoisomerase I previously separated were either recombined (B) or separately (C, topoisomerase; D RNA polymerase) concentrated and then dialyzed for $3 \mathrm{~h}$ against buffer containing $20 \mathrm{mM}$ $\left(\mathrm{NH}_{4}\right)_{2} \mathrm{SO}_{4}$

ribosomal RNA synthesis proceeds at approximately $80 \%$ of the normal rate and the actively transcribed genes can be visualized as a beaded structure using anti-RNA polymerase I antibodies and indirect immunofluorescence (Scheer et al. 1984). Thus treatment of cells with DRB allows precise localization of ribosomal gene transcription units at the level of light microscopy. Therefore we exam- 


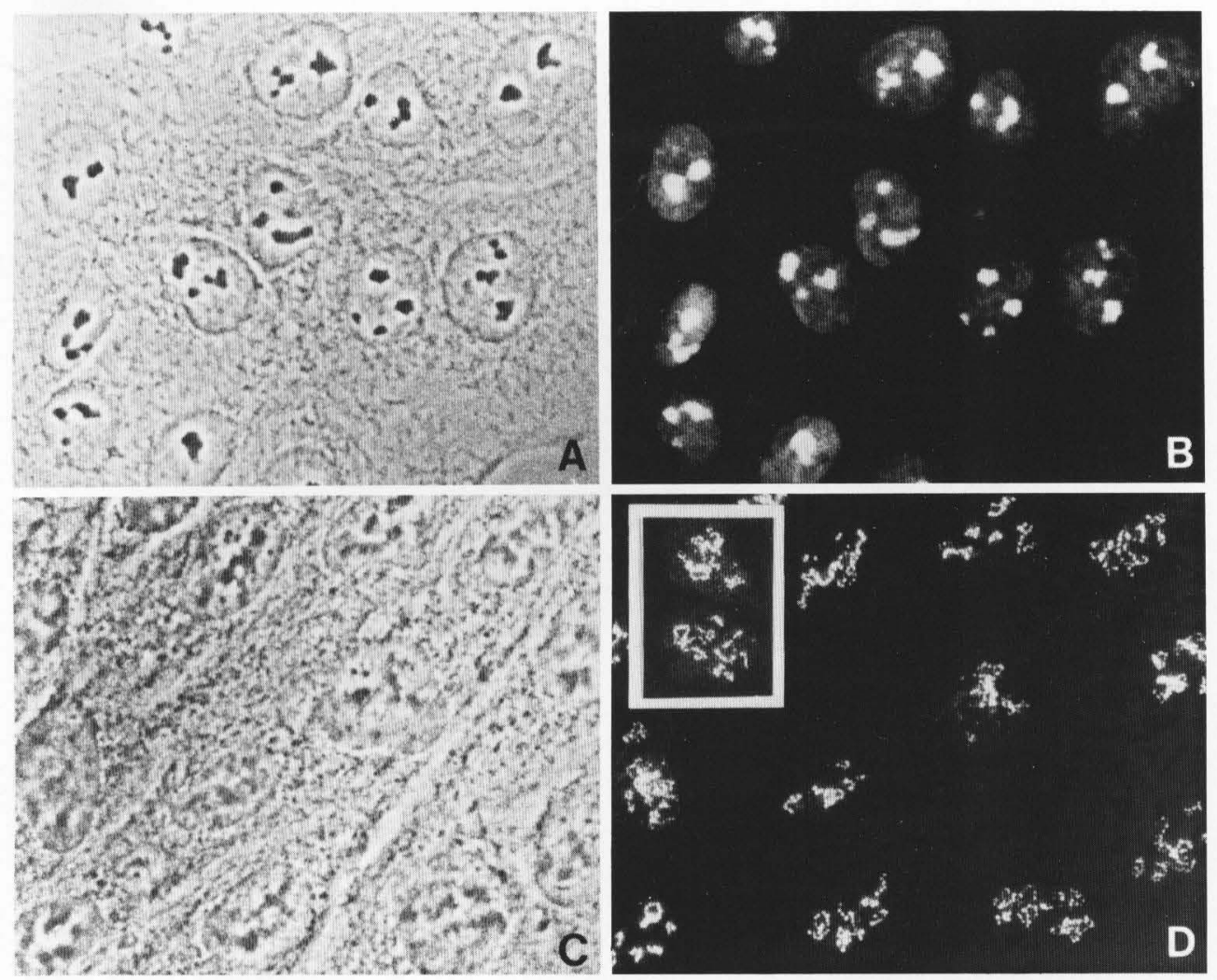

Fig. 6A-D. Immunocytochemical localization of topoisomerase I. Rat cells were grown in the absence $(\mathbf{A}, \mathbf{B})$ and presence $(\mathbf{C}, \mathbf{D})$ of DRB (5,6-dichloro-D-ribofuranosylbenzimidazole) as described by Scheer et al. (1984). Cells were fixed and incubated with affinity purified monospecific anti-topoisomerase I antibodies raised in rabbit against enzyme purified from calf thymus and processed as described in Scheer and Rose (1984). A, C Phase contrast photomicrographs. B, D, Fluorescence photomicrographs. Inset in D, DRB-treated cells incubated with anti-RNA polymerase I antibodies

ined the immunofluorescent pattern of topoisomerase $\mathrm{I}$ in cells treated with DRB. As shown in Figure 6D, the topoisomerase I appears as a series of tandemly arrayed dots, indistinguishable from the pattern obtained using antiRNA polymerase I antibodies which is shown in the inset for comparison. It should be noted that the antibodies against RNA polymerase I react predominantly with the $M_{r} 190000$ polypeptide of the polymerase and that monoclonal antibodies against the $\mathrm{M}_{\mathrm{r}} 190000$ subunit display an analogous pattern to those of the polyclonal antibodies. Other experiments using the anti-topoisomerase I antibodies indicate that the enzyme can be located in the "caps" of segregated nucleoli of actinomycin D treated cells, in the fibrillar centers of nucleoli of tissue prepared for electron microscopy and at the nucleolar organizer regions of metaphase chromosomes (not shown; see also Guldner et al. 1986). In no case can we distinguish the nucleolar pattern from that using anti-RNA polymerase I antibodies. It should be pointed out, however, that in contrast to the strict nucleolar location of RNA polymerase I, topoisomerase I is present both in the nucleolus and the nucleoplasm. As judged from immunofluorescence microscopy, the relative proportion of nucleolar and extranucleolar topoisomerase I seems to be quite variable in different cell types examined.

\section{Discussion}

Our data indicate that topoisomerase I can copurify with RNA polymerase I through a variety of ion exchange and affinity chromatography steps as well as sucrose gradient centrifugation or gel filtration steps which contain less than $0.25 \mathrm{M}\left(\mathrm{NH}_{4}\right)_{2} \mathrm{SO}_{4}$. That the association of the enzymes represents a true complex rather than simple copurification of the two enzymes is demonstrated by their ability to be reassociated following disassociation and separation. Further, the complex of the two enzymes in vitro is sufficiently strong that anti-topoisomerase antibodies bound to the topoisomerase component of the complex can prevent transcription or remove polymerase from solution. It should be noted that although the topoisomerase has an $\mathrm{M}_{\mathrm{r}}$ similar to one of the polymerase polypeptides, the topoisomerase does not significantly contribute to the mass of that polymerase polypeptide (less than $25 \%$ ) and, indeed, polymerase I purified under stringent conditions still has a $\mathrm{M}_{\mathrm{r}} 110000$ polypeptide and no topoisomerase activity. Thus topoisomerase should be viewed as a polymerasebinding enzyme rather than as a subunit. This idea is further strengthened by the fact that, at least on calf thymus DNA, topoisomerase activity is not required for transcription.

The close association between topoisomerase and RNA polymerase I in vitro suggests a role for the topoisomerase in ribosomal gene transcription in vivo. This hypothesis is strongly supported by our observation that these two molecules can be immunocytochemically localized on the same structure in situ. In particular the colocalization of the two enzymes on the DRB-extended nucleolar chromatin provides direct evidence that the topoisomerase is found at the site of ribosomal RNA synthesis. While this manuscript was under review, Zhang et al. (1988) published data implicating a role for topoisomerase I in ribosomal gene transcription in vivo. Taken together with the present study, 
it seems highly likely that the action of this topoisomerase is required for proper synthesis of rRNA.

Acknowledgements. The authors wish to thank Ms Nubia Alban and Ms Barbara Cochran for excellent technical assistance. This work was supported by grants GM-33442 (K.M.R.) and CA-27448 (Y.C.C.) from the USPHS, and Sch-157/5-4 (U.S.) from the Deutsche Forschungsgemeinschaft.

\section{References}

Akrigg A, Cook PR (1980) DNA gyrase stimulates transcription. Nucleic Acids Res 8:845-854

Bonven BJ, Gocke E, Westergaard O (1985) A high affinity topoisomerase I binding sequence is clustered at DNAase I hypersensitive sites in Tetrahymena R-chromatin. Cell 41:541-551

Bullock P, Champoux JJ, Botchan M (1985) Association of crossover points with topoisomerase I cleavage sites: a model for nonhomologous recombination. Science 230:954-958

Champoux JJ, Dulbecco R (1972) An activity from mammalian cells that untwists superhelical DNA-A possible swivel for DNA replication. Proc Natl Acad Sci USA 69:143-146

Duceman BW, Rose KM, Jacob ST (1981) Activation of purified hepatoma RNA polymerase I by homologous protein kinase NII. J Biol Chem 256:10755-10758

Durban E, Goodenough M, Mills J, Busch H (1985) Topoisomerase I phosphorylation in vitro and in rapidly growing Novikoff hepatoma cells. EMBO J 4:2921-2926

Dynan WS, Burgess R (1981) In vitro transcription by wheat germ RNA polymerase II. J Biol Chem 256:5866-5873

Ferro AM, Olivers BM (1984) Poly(ADP-ribosylation) of DNA topoisomerase I from calf thymus. J Biol Chem 259:547-554

Fleischmann G, Pflugfelder G, Steiner EK, Javaherian K, Howard GC, Wang JC, Elgin S (1984) Drosophila DNA topoisomerase $I$ is associated with transcriptionally active regions of the genome. Proc Natl Acad Sci USA 81:6958-6962

Garg LC, DiAngelo S, Jacob ST (1987) Role of DNA topoisomerase I in transcription of supercoiled rRNA gene. Proc Natl Acad Sci USA 84:3185-3188

Gellert M (1981) DNA Topoisomerases. Annu Rev Biochem 50:879-910

Gilmour DS, Pflugfelder G, Wang JC, Lis JT (1986) Topoisomerase I interacts with transcribed regions in Drosophila cells. Cell 44:401-407

Guldner H, Szostecki H, Vosberg H, Lakomek H, Penner E, Bautz FA (1986) Scl 70 autoantibodies from scleroderma patients recognize a $95 \mathrm{kDa}$ identified as DNA topoisomerase I. Chromosoma 94:132-138

Jacob ST, Rose KM (1978) RNA polymerase and poly(A)polymerase from neoplastic tissues and cells. Methods Cancer Res 14:191-241

Jonstra-Bilen J, Ittel M, Niedergana C, Vosberg H, Mandel P (1983) DNA topoisomerase I from calf thymus is inhibited in vitro by poly(ADP-ribosylation). Eur J Biochem 136:391-396

Keller W (1975a) Characterization of purified DNA-relaxing enzyme from human tissue culture cell. Proc Natl Acad Sci USA $72: 2550-2554$

Keller W (1975b) Determination of the number of superhelical turns in simian virus 40 DNA by gel electrophoresis. Proc Natl Acad Sci USA 72:4876-4880

Kikuchi Y, Nash HA (1979) Nicking-closing activity associated with bacteriophage int gene product. Proc Natl Acad Sci USA $76: 3760-3764$

Köhler G, Milstein C (1975) Continuous cultures of fused cells secreting antibody of predefined specificity. Nature 256:495-497

Laemmli UK (1970) Cleavage of structural proteins during the assembly of the head of bacteriophage T4. Nature 227:680-685
Liu L (1984) DNA topoisomerases-Enzymes that catalyse the breaking and rejoining of DNA. CRC Crit Rev Biochem 14:1-24

Muller MT, Pfund WP, Mehta VB, Trask DR (1985) Eukaryotic type I topoisomerase is enriched in the nucleolus and catalytically active on ribosomal DNA. EMBO J 4:1237-1243

Roeder RG (1976) Eukaryotic nuclear RNA polymerase. In: Losick R, Chamberlin M (eds) RNA polymerase. Cold Spring Harbor Laboratory, Cold Spring Harbor, New York, pp 285389

Rose KM, Ruch PA, Morris HP, Jacob ST (1976) RNA polymerases from a rat hepatoma; partial purification and comparison of properties with corresponding liver enzymes. Biochim Biophys Acta 432:60-72

Rose KM, Bell LE, Siefkin DA, Jacob ST (1981a) A heparinsensitive nuclear protein kinase. J Biol Chem 256:7468-7477

Rose KM, Stetler DA, Jacob ST (1981 b) Protein kinase activity of RNA polymerase I purified from a rat hepatoma: probable function of $M_{r} 42000$ and 24600 polypeptide. Proc Natl Acad Sci USA 78:2833-2837

Rose KM, Duceman BW, Jacob ST (1983) RNA polymerase I in hepatoma 3924A: mechanism of enhanced activity relative to liver. Adv Enzyme Regul 21:307-319

Scheer U, Rose KM (1984) Localization of RNA polymerase I in interphase cells and mitotic chromosomes by light and electron microscopic immunocytochemistry. Proc Natl Acad Sci USA $81: 1431-1435$

Scheer U, Hugle B, Hazan R, Rose KM (1984) Drug-induced dispersal of transcribed rRNA genes and transcriptional products: immunolocalization and silver staining of different nucleolar components in rat cells treated with 5,6-dichloro-D-ribofuranosylbenzimidazole. J Cell Biol 99:672-679

Schmitt B, Buhre Y, Vosberg H (1984) Characterization of size variants of type I DNA topoisomerase isolated from calf thymus. Eur J Biochem 144:127-134

Shastry BS (1986) 5S RNA gene specific transcription factor (TFIIIA) changes the linking number of the DNA. Biochem Biophys Res Commun 134:1086-1092

Shero JH, Bordwell B, Rothfield NF, Earnshaw WC (1986) High titers of autoantibodies to topoisomerase I (Scl-70) in sera from scleroderma patients. Science 231:737-740

Sternglanz R, DiNardo D, Voelkel KA, Nishimure Y, Hirota Y, Becherer K, Zumstein L, Wang JC (1981) Mutations of the gene coding for Escherichia coli DNA topoisomerase I affect transcription and transposition. Proc Natl Acad Sci USA $78: 2747-2751$

Szopa J, Rose KM (1986) Cleavage of the 190-kDa subunit of DNA-dependent RNA polymerase I yields small polypeptides capable of degrading DNA. J Biol Chem 261:9022-9028

Vosberg H-P (1985) DNA topoisomerase: Enzymes that control DNA conformation. Curr Top Microbiol Immunol 114:19-102

Wang JC (1971) Interaction between DNA and an Escherichia coli protein. J Mol Biol 55:523-533

Wang JC (1985) DNA topoisomerases. Annu Rev Biochem $54: 665-697$

Weisbrod ST (1982) Properties of active nucleosomes as revealed by HMG 14 and 17 chromatography. Nucleic Acids Res $10: 2017-2042$

Zeng GC, Zannis-Hadjopoulos M, Ozer HL, Hand R (1985) Defective DNA topoisomerase I activity in a DNA ts mutant of balb/ 3 T3 cells. Somatic Cell Mol Genet 11:557-569

Zhang H, Wang JC, Liu LF (1988) Involvement of DNA topoisomerase I in transcription of human ribosomal RNA genes. Proc Natl Acad Sci USA 85:1060-1064

Received January 27, 1988

Accepted by W. Hennig 